Аніко Берегсасі, доктор філософії, доцент завідувач кафедри філології Закарпатського угорського інституту імені Ференца Ракоці II

ORCID: 0000-0001-6860-7579 beregszaszi.aniko@kmf.uz.ua

Вільмош Газдаг, доктор філософії, доцент кафедри філології Закарпатського угорського інституту імені Ференца Ракоці II ORCID: 0000-0002-9331-2307 gazdagvilmos@gmail.com Степан Черничко, доктор гуманітарних наук (філологія), професор, професор кафедри філології Закарпатського угорського інституту імені Ференца Ракоці II та Університету Паннонія (м. Веспрем, Угорщина)

ORCID: 0000-0003-4512-988X csernicsko.istvan@kmf.uz.ua

\title{
МОВНА ПОЛІТИКА І МОВНИЙ ЛАНДШАФТ: ПОЛЬСЬКА МОВА НА БАНКНОТАХ ЧЕХОСЛОВАЦЬКОЇ РЕСПУБЛІКИ 1919-1938 РР.
}

У публікачії досліджуються мови, які були представлені в написах різних серій банкнот, виданих у період між першою та другою світовими війнами (1919-1938 рр.) у

Чехословацькій Республіиі. Поряд із портретами історичних діячів, зображеннями, шьо стосуються культури та історичного минулого певної нації, присутність (чи відсутність) на банкнотах мов також є елементом символічної політики та частиною виявлення мовної

політики певної держави. Банкноти розглядаються як елемент мовного ландшафту, а мовний ландшафт - як віддзеркалення мовної політики, ї̈ своєрідне публічне вираження. $У$ статті проаналізовані причини появи й зникнення польської мови як однієї з мов національних меншин Чехословаџької Республіки на банкнотах зазначеного періоду. Автори дійшли до висновків, щзо навіть держави, які видають багатомовні банкноти, гарантують, що державна мова повинна бути в панівній позииіі.

Ключові слова: банкноти, мовна політика, мовний ландшафт, польська мова, Чехословаџька Республіка.

Anikó Beregszászi, Vilmos Gazdag, István Csernicskó. Polityka językowa i krajobraz językowy: język polski na banknotach Republiki Czechostowackiej 1919-1938 w latach

Artykut analizuje języki, które występowaty w napisach różnych serii banknotów emitowanych $w$ okresie między I a II wojna światowa (1919-1938) w Republice Czechostowackiej. Obok portretów postaci historycznych, obrazów zwiąanych z kultura i historyczna przeszłościa danego narodu, obecność (lub nieobecność) na banknotach języków jest także elementem polityki symbolicznej $i$ elementem identyfikacji polityki językowej danego państwa. Banknoty traktowane sa jako element

krajobrazu językowego, a krajobraz językowy-jako odzwierciedlenie polityki językowej, jej pierwotny wyraz publiczny. Artykut analizuje przyczyny pojawiania się i zanikania języka polskiego jako jednego z języków mniejszości narodowych Republiki Czechostowackiej na banknotach z określonego okresu. Autorzy dochodza do wniosku, że nawet państwa, emitując banknoty wielojęzyczne, gwarantują dominująca pozycje języka państwowego. 

Czechosłowacka.

\section{Anikó Beregszászi, Vilmos Gazdag, István Csernicskó. Language policy and linguistic} landscape: Polish on the banknotes of the Czechoslovak Republic 1919-1938

This publication examines which languages were represented in the inscriptions of different series of banknotes issued between the First and Second World Wars (1919-1938) in the Czechoslovak Republic. Along with portraits of historical figures, images relating to the culture and history of a particular nation, the presence (or absence) of banknotes of languages is also an element of symbolic politics and part of the manifestation of the language policy of a particular state. Banknotes are seen as an element of the linguistic landscape, and the linguistic landscape is understood as a reflection of language policy, its peculiar public expression.

The main purpose of the study was to show why the Polish language appeared on the banknotes of Czechoslovakia, which were in circulation between 1919 and 1925, and to analyse why the Polish language disappeared from paper money after 1926.

Placed languages on banknotes are subject to quantitative and qualitative analysis, examines the location of languages, the relationship between them. It is shown that the concept of "linguistic landscape" is not only an analysis of signs in public places, it can be interpreted and investigated in various ways. We believe that part of the increasingly interpreted linguistic landscape may also be the analysis of languages used in monetary units. It is noted that the historical approach to the analysis of the linguistic landscape helps to clarify aspects of language policy and linguistic ideologies.

The authors conclude that even states that issue multilingual banknotes guarantee that the state language should be in a dominant position. The article shows why the Ukrainian, German, Polish and Hungarian languages appeared next to Czech and Slovak on the banknotes of the first issue of the Czechoslovak Republic.

The Polish language was reflected on Czechoslovak banknotes that were in circulation between 1919-1925, but Prague removed the Polish language from paper money after 1926. The article analyses the reasons for the appearance and disappearance of the Polish language on the banknotes of the Czechoslovak Republic.

Keywords: banknotes, language policy, linguistic landscape, polish language, Czechoslovak Republic.

Постановка проблеми й аналіз останніх досліджень та публікацій. Дослідження, присвячені мовному ландшафту (англійською: Linguistic Landscape), спрямовані насамперед на вивчення того, як проявляється мова в громадських місцях, у публічному просторі [21]. У першій хвилі досліджень мовного ландшафту використовували переважно квантитативну методику [37], зосереджувалися насамперед на тому, що Е. Шогамі і Е. Бен-Рафаель характеризують так: дослідження мовного ландшафту не що інше, ніж «тлумачення присутності, представництва та значення мов, які з'являються в публічному просторі» [56, c. 1]. 3 метою усунення недоліків перших досліджень мовного ландшафту А. Яворські та К. Турлоу ввели поняття семіотичного ландшафту [31] і замість квантитативного аналізу акцентували на ширшому семіотичному аналізі знаків, що знаходяться в публічному просторі [45, с. 270$]$.

Теоретичні питання, пов'язані з вивченням мовного ландшафту, розглянуто в багатьох узагальнювальних працях $[21 ; 22 ; 7 ; 54]$, тому ми утримаємося від детального роз'яснення поняття «мовний ландшафт», 3'ясування історії дослідження теми та дилеми про методологію. Однак зазначимо, що вже перші розвідки в цій сфері визначили дві базові функції написів, що з'являються в публічному просторі: комунікативну та символічну.

Із комунікативною функцією все просто: щось пишуть для того, щоб доносити до людей інформацію. У випадку написів, що виконують винятково комунікативну функцію, доцільно, 
Аніко Берегсасі, Вільмоши Газдаг, Степан Черничко. Мовна політика і мовний ландшафт: Польська мова на банкнотах чехословацької республіки 1919-1938 рр.

щоб ті, що є авторами таблиць і написів, подавали інформацію тією мовою (чи мовами), якою (чи якими) вона може бути донесена цільовій аудиторії.

Мета символічних написів значно глибша, ніж просто донесення інформації до читачів. Символічні написи, крім базової інформації, містять певний додатковий підтекст. Символічна функція отримала значно більшу, ніж у попередні епохи, роль у добу поширення європейського національного романтизму та ідеї національної держави. Із того часу в Європі поступово поширювалася практика, коли мова панівної державотворчої нації відображалася в публічних написах не тільки офіційного чи комерційного характеру, але й у громадській та частково навіть у церковній царині. Отож у публічних написах не завжди з'являлася та мова, яку найкраще розуміли оточуючі, а та, якій привласнювали символічні функції. У цьому дослідженні спробуємо розглянути й проаналізувати мовний ландшафт саме 3 погляду символічної функції.

У міжнародній фаховій літературі поступово розширюється тематика досліджень, присвячених мовному ландшафту, тож постійно набуває нових тлумачень і саме поняття. Сьогодні його частиною стала мова документів, офіційних бланків, візитних карток, так само, як, наприклад, етикетки на товарах $[6 ; 36 ; 57 ; 59$ тощо].

Мовний ландшафт, що став базовим поняттям порівняно нового напрямку досліджень, багато хто трактує як віддзеркалення мовної політики, своєрідне іiі публічне вираження [53, с. $112 ; 55 ; 60$, с. 5]. Е. Шогамі [53] зображує мовний ландшафт як арену боротьби за владу, контроль, національну ідентичність і самовираження [53]. Як відзначає, наприклад, С. Дел Негро, «мовний ландшафт робить мовну політику одразу видимою» [17, с. 206]. Це насамперед $\epsilon$ наслідком того, що мови, які з'являються в мовному ландшафті, виконують символічну функцію. Тому науковці аналізують соціальне та культурне розміщення знаків у мовному ландшафті і прагнуть описати соціальний зміст матеріального розміщення знаків $\mathrm{i}$ дискурсів [51].

Те, які мови і як можуть з'являтися чи з'являються в мовному ландшафті в широкому його розумінні, відображає мету мовної політики певної держави, а також дає інформацію про мовну ідеологію та позицію влади. Аналіз певних сегментів мовного ландшафту дає змогу розкрити, якою бажає показати владна еліта свою мовну політику. Вивчення окремих елементів мовного ландшафту допомагає зрозуміти ті мовні ідеології, які політикум, що їх формує, має намір спрямувати назовні [13, с. 244; 35].

Завдяки вивченню мовного ландшафту можна краще пізнати мету й прагнення мовної політики, розкрити ідеології, що приховалися за мовною політикою [55]. Згідно із визначенням К. Бохманна, мовна політика - «це регулювання практики комунікації суспільства такою групою, яка має мовну та культурну гегемонію або намагається іiі досягти. (...) Мовна політика, як і будь-який інший різновид політики, (...) підпорядкована інтересам певних груп, прошарків, класів» [15, с. 26-31].

За спостереженням А. Павленко, дослідження мовного ландшафту сприяє кращому виявленню відносин мови й ідентичності, розкриттю мовних ідеологій [42, с. 247-248]. Однак дослідниця розглядає мовний ландшафт не як явище «тут і зараз», а як діахронне та динамічне. Вона тлумачить мовний ландшафт як процес, взаємозв'язаний з іншими мовними практиками, а також розглядає елементи мовного ландшафту як учасників суспільних i мовних змін [42; 44]. Інші дослідники вважають, що «зміна в публічній сфері може бути наслідком зміни у мовній політиці» [25, с. 482].

Н. Ферклау слушно зауважує, що «ідеології тісно пов'язані з владою» й «ідеології тісно пов'язані $з$ мовами» [19, с. 2]; а також «ідеології живуть у текстах» [18, с. 71]. Нижче, відповідно до положень праці «The visual construction of language hierarchy: The case of banknotes, coins and stamps» [52], ми розглядаємо банкноти як елемент мовного ландшафту [1; 16]. Хоча у XXI столітті обсяги та значення готівкового обігу поступово зменшуються, однак кожна держава надавала зображенням на паперових грошах символічного значення, тож ми також розглядаємо їх під таким кутом зору. Поряд із портретами історичних діячів, 
зображеннями, що стосуються культури та історичного минулого певної нації, присутність (чи відсутність) на банкнотах мов також є елементом символічної політики та частиною виявлення мовної політики певної держави [48, с. 930; 52].

Випуск банкнот суворо регулюється державою, при цьому контролюється не тільки форма, колір, декоративні елементи, номінали та елементи захисту банкнот, але й символи та мови, які на них 3'являються [29]. Мови на банкнотах «завжди будуть продуктом домінуючих мовних ідеологій», - пише М. Себба [52, с. 104]. Проте необхідно зазначити: зображення, яке бажають нам транслювати, не обов'язково розкриває справжні цілі мовної політики, адже трансльована загалу картинка не завжди збігається з реальними політичними мотиваціями, що залишаються прихованими [53, с. 54]. «Реальна» політика може суперечити «декларованій», хоча формальна документація у сфері мовної політики, безперечно, $\epsilon$ частиною процесу, спрямованого на створення «реальної» ситуації [47, с. 128]. Саме тому аналізуємо паперові гроші як одну з можливих форм виявлення мовної політики та мовної ідеології.

У цьому дослідженні розглянуто - на основі доступних для нас джерел - у межах теорії мовної політики певний сегмент мовного ландшафту 3 чітко визначеної оригінального підходу. Простежимо, які мови з'являлися на паперових грошах, що були в обігу в Чехословацькій Республіці з 1919 по 1938 рр. У такий спосіб у цій публікації потрактовуємо мовний ландшафт у контексті мовної політики, зосереджуючи увагу на конкретному явищі (мова на грошових одиницях).

Аналіз мовного ландшафту розглядаємо як динамічно змінний процес та використовуємо відповідний підхід для виявлення й тлумачення тих мовних та політичних ідеологій, які стоять за кулісами рішень і дій мовної політики.

Мета дослідження - показати, чому з'явилася польська мова на банкнотах Чехословаччини, що були в обігу між 1919 та 1925 pp., і проаналізувати, з яких причин вона зникла з паперових грошей після 1926 року.

Методика дослідження. Мовний ландшафт став об'єктом наукового вивчення нещодавно, тож методика його дослідження ще тільки формується [21, с. 3; 63]. На це вказує й те, що ні в численних збірниках, присвячених цій темі $[7 ; 12 ; 23 ; 24 ; 32 ; 38 ; 50 ; 58]$, ні в журналі «Linguistic Landscape: An International Journal» не викристалізувався такий методичний підхід, дотримання якого стало б загальноприйнятним та очікуваним для дослідників цієї царини. Однак існують методичні рекомендації та принципи, які ми також взяли до уваги в нашому дослідженні. Наприклад, на переконання укладачів збірника «Minority Languages in the Linguistic Landscape», у дослідженнях мовного ландшафту необхідно комбінувати критерії квантитативного та квалітативного аналізу [39, с. 3]. Інші науковці звертають увагу, що до мовного ландшафту можна й потрібно застосовувати не тільки синхронний підхід; наголошують на необхідності аналізувати мовний ландшафт як постійно змінне, динамічне явище $[5 ; 42 ; 44 ; 34]$. Д. Гортер, розглядаючи методику дослідження мовного ландшафту, акцентує на міждисциплінарних підходах [20, с. 86]. Науковець відзначає, що історичний підхід при вивченні мовного ландшафту не дуже поширений, але може застосовуватися як техніка аналізу [20, с. 88].

Застосовуючи вказані вище підходи, у цій публікації ми проаналізуємо банкноти, що використовувалися в державі Чехословацька Республіка, котра з'явилася після першої світової війни від перших днів нової країни до початку другої світової війни. Паперові гроші розглядаємо як елемент мовного ландшафту, а розміщені на них написи (мови) піддамо квантитативному та квалітативному аналізу, розглянемо їх розташування, взаємовідносини. Ми покажемо, що поняття «мовний ландшафт» - це не тільки аналіз вивісок у громадських місцях, його можна трактувати та досліджувати різними способами. Вважаємо, що частиною все ширше трактованого мовного ландшафту може бути й аналіз мов, які використовуються на грошових одиницях. Погоджуючись із багатьма дослідниками цієї теми, відзначимо, що історичний підхід до аналізу мовного ландшафту сприяє з'ясуванню аспектів мовної 
політики та мовних ідеологій [5; 43]. При цьому замість квантитативного методу, на якому довгий час акцентували в дослідженнях мовного ландшафту, ми віддаємо перевагу квалітативному аналізу [14] та зосередимося на розкритті семіотичних характеристик окремих банкнот. У статті ми покажемо, як і чому з'явилася польська мова на банкнотах Чехословаччини та як і чому вона зникла з паперових грошей через певний час.

Виклад основного змісту з обгрунтуванням отриманих наукових результатів.

Мови на чехословацькій кроні.

Перша Чехословацька Республіка була заснована в жовтні 1918 року як один із правонаступників Австро-Угорської монархії. 8 травня 1919 року в Парижі було ухвалено рішення про те, що Чехословаччина отримає й сучасну територію Закарпатської області України під назвою Підкарпатська Русь, про що й було зафіксовано в Сен-Жерменському мирному договорі 10 вересня 1919 року.

Власна грошова одиниця нової держави була запроваджена 10 квітня 1919 року. Чехословацька крона замінила крону Австро-Угорської монархії. Лицьова частина нової крони, випущеної ще до прийняття Конституції Чехословацької Республіки та Закону «Про мови», була одномовною - чеською (фото 1 та 3).

Відповідно до § 18 Закону №347/1920, ухваленого 14 квітня 1920 року, номінал паперових грошей на зворотному боці крони вказувався двома мовами - чеською та словацькою. Однак текст чеською мовою мав домінантне розташування на цих перших банкнотах: він знаходився у верхній частині банкноти, натомість напис словацькою був розміщений внизу серед написів іншими мовами національних меншин, тобто українською / руською, німецькою, польською та угорською (фото 2 та 4).

Отже, символіка банкноти вказує на те, що словацька в Чехословацькій державі тоді була ще однією з мов меншин. Словаки виступили проти такої практики, яка, на їх думку, однозначно фіксувала провідну позицію чехів і чеської мови в державі, й вимагали, щоб на певних банкнотах (наприклад, номіналом 10 і 50 крон) лицевий бік був одномовним - 3 написом словацькою мовою [64, с. 243].

Фото 1

Одномовний лицевий бік банкноти номіналом 1000 крон, що була в обігу в першій Чехословацькій Республіці протягом 1919-1925 років

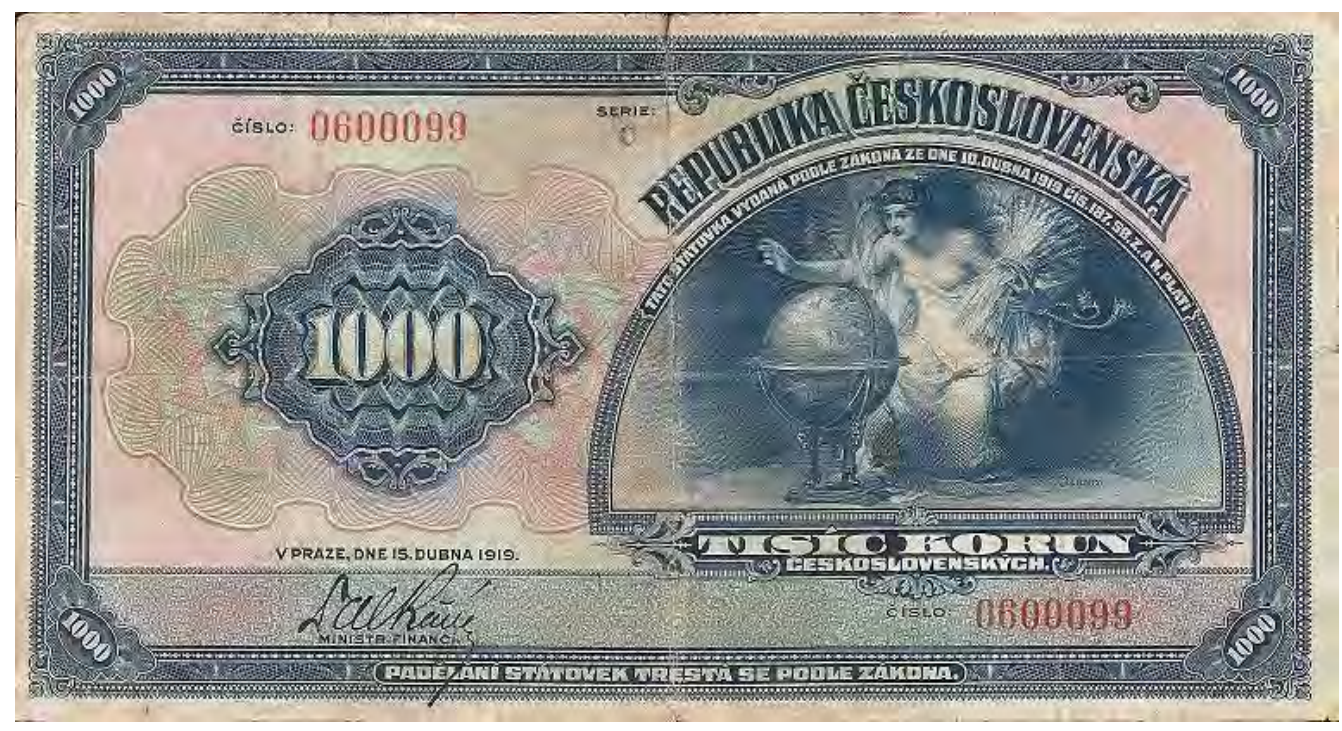


Зворотний бік банкноти номіналом 1000 крон, що була в обігу в першій Чехословацькій Республіці протягом 1919-1925 років (номінал указаний чеською, словацькою, українською / руською, німецькою, польською й угорською мовами)

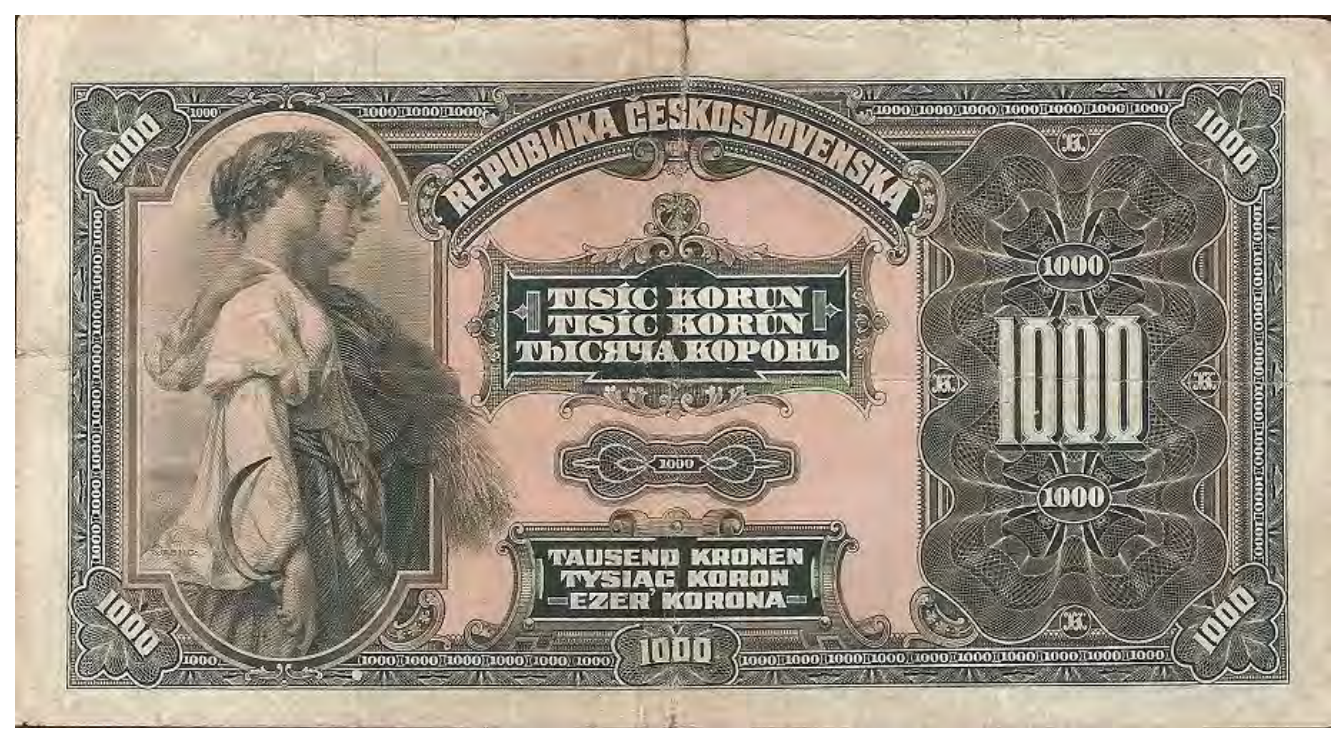

Незабаром така практика розміщення мов змінилася, коли Конституція забезпечила ідеологічну основу творення нової держави. У новій державі мовні права регулював Закон «Про мови», що був частиною Конституції. Згідно з §1 Закону №122 «Про мови», ухваленого 29 лютого 1920 року, державною й офіційною мовою республіки була «чехословацька» [2, c. 69-75].

За поняттям «чехословацької» мови стояла ідея єдності національної держави: так звана ідеологія чехословакізму [33, с. 518-521; 64, с. 242-243].

Фото 3

Одномовний лицевий бік банкноти номіналом 1 крона, що була в обігу в першій Чехословацькій Республіці протягом 1919-1925 років

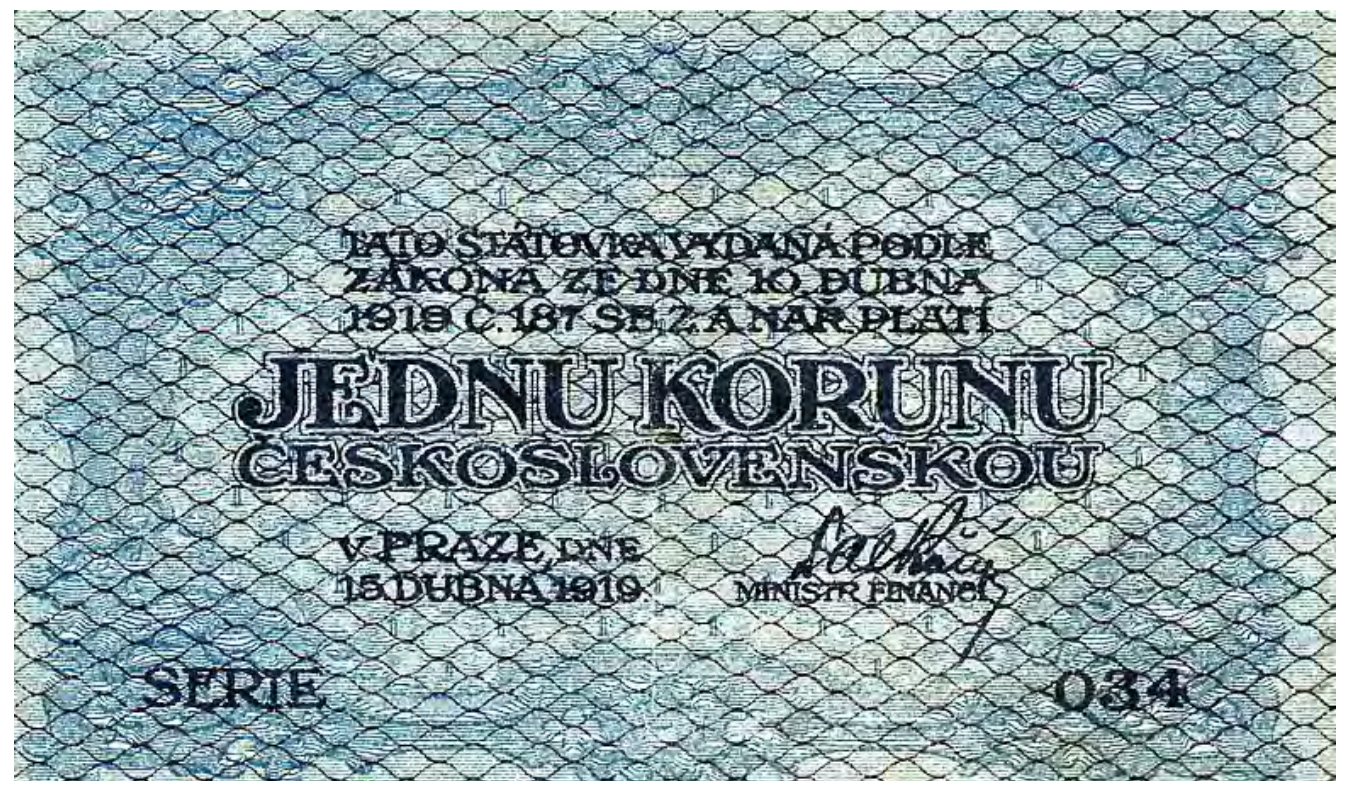


Зворотний бік банкноти номіналом 1 крони, що була в обігу в першій Чехословацькій Республіці протягом 1919-1925 років (номінал указаний чеською, словацькою, українською / руською, німецькою, польською й угорською мовами)

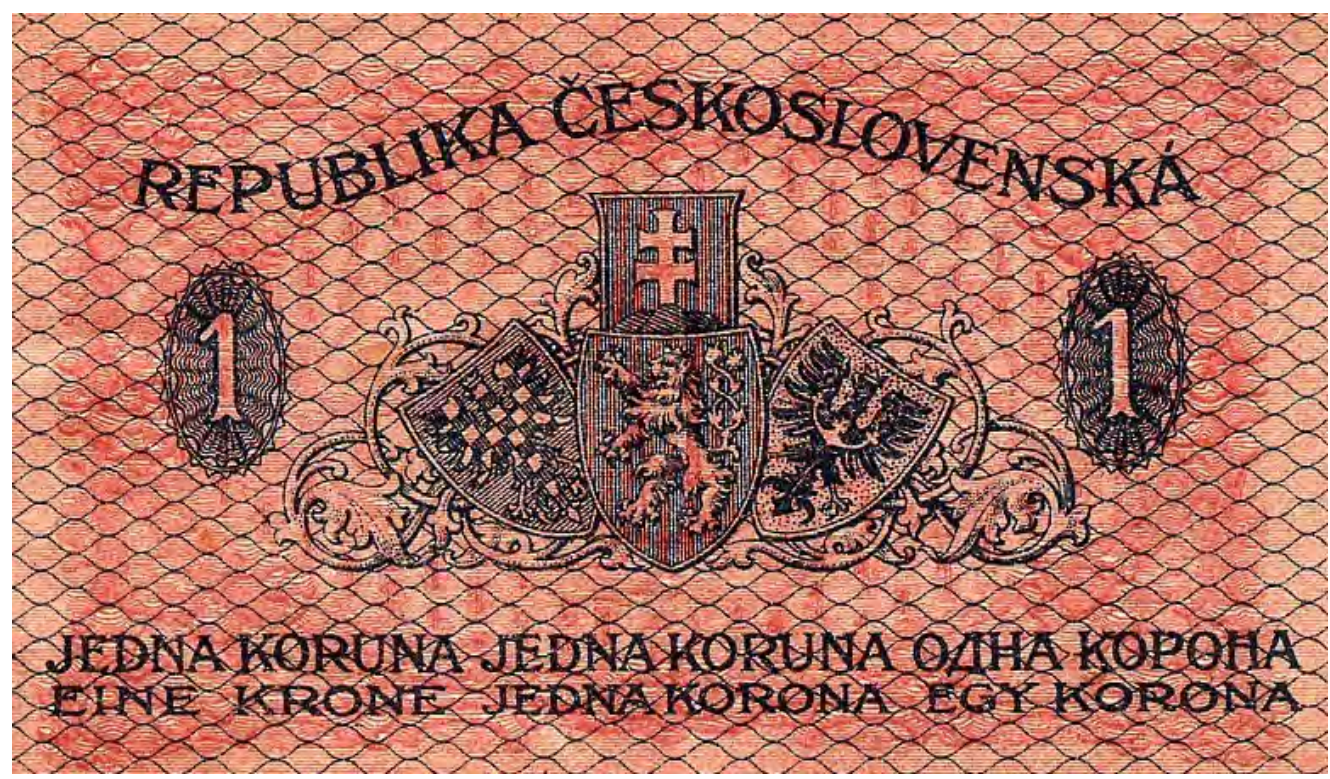

Після Першої світової війни нові держави, що виникали на руїнах Австро-Угорської монархії, хоч і базувалися на праві націй на самовизначення, але формувалися як національні тільки теоретично. «Чехословацька Республіка була створена як національна держава держава чехословацької нації - але насправді вона була багатонаціональним державним утворенням. Третина її громадян (у 1921 році - 34,3 \%, а в 1931 році - 32,7 \%) належала до інших національностей», - писав Р. Поміхал [46, с. 64]. Частка чехів, найбільшого етносу, у новій державі була нічим не більшою, ніж частка угорців в Угорщині перед розпадом монархії. Згідно з даними перепису населення 1910 року, на території Угорського Королівства частка осіб, що вказала рідною угорську мову, становила 54,4 \% від загальної кількості населення [49, с. 49], а чехи у 1921 році складали 51,1\% населення Чехословаччини, через десятиліття їх частка зросла до 55,4 \%. Після чехів найчисленнішим етносом були не словаки, а німці, що вважалися національною меншиною, а загалом становили більше п'ятої частини населення республіки. Частка словаків була більшою, ніж угорців, які теж трактувалися як нацменшина, однак чисельність угорців була значно вищою, ніж українців / русинів, яким було обіцяно автономію та для яких було створено окрему територіальноадміністративну одиницю - Підкарпатська Русь (таблиця № 1).

У таблиці № 1 ми знайдемо відповідь на те, чому саме українська / руська, німецька, польська й угорська мови з'явилися поруч із чеською та словацькою на банкнотах першого випуску Чехословацької Республіки: ці мови $\epsilon$ рідними найпотужніших національних меншин нової незалежної держави. Тобто польська мова з'явилася на грошових одиницях Чехословаччини як мова національної меншини. 
Національний склад населення Чехословаччини за даними переписів 1921 та 1930 років

\begin{tabular}{|l|r|r|r|r|}
\hline \multirow{2}{*}{ Національність } & \multicolumn{2}{|c|}{1921} & \multicolumn{2}{c|}{1930} \\
\cline { 2 - 5 } & осіб & \multicolumn{1}{c|}{$\%$} & \multicolumn{1}{c|}{ осіб } & \multicolumn{1}{c|}{ \% } \\
\hline чехи & 6831120 & $51,1 \%$ & 7406493 & $55,4 \%$ \\
\hline словаки & 1967870 & $14,7 \%$ & 2282277 & $17,1 \%$ \\
\hline німці & 3123568 & $23,4 \%$ & 3231688 & $24,2 \%$ \\
\hline угорці & 745431 & $5,6 \%$ & 691923 & $5,2 \%$ \\
\hline українці & 461849 & $3,5 \%$ & 549169 & $4,1 \%$ \\
\hline поляки & 75853 & $0,6 \%$ & 81737 & $0,6 \%$ \\
\hline євреї & 180855 & $1,4 \%$ & 186642 & $1,4 \%$ \\
\hline інші & 25871 & $0,2 \%$ & 49636 & $0,4 \%$ \\
\hline всього & 13374364 & $100,0 \%$ & 14479565 & $100,0 \%$ \\
\hline
\end{tabular}

Ідеологія чехословакізму, що проголошувала єдність чехів і словаків, а також чеської та словацької мов, намагалася знайти рішення тієї проблеми, що Чехословацька Республіка зовсім не була гомогенною національною державою [61, с. 127].

Е. Бенеш у виданій ще в 1916 році французькою мовою в Парижі праці «Détruisez l' Autriche-Hongrie: La Martyre des Tcehecoslovaques a travers histoire» висловлювався так: «Чехословаки, або просто чехи, складаються з двох елементів: із семи мільйонів чехів, які проживають у Чехії, Моравії та Сілезії, та $з$ трьох мільйонів словаків, які проживають у північній частині Угорщини, від місця злиття Морави та Дунаю до Верхньої Тиси. [...] Це дві гілки тотожної нації, одна й та сама культура, одна й та сама мова, одна й та сама історія: словацький діалект лише трохи відмінний від чеського» [8, с. 5]. У пізнішій уже англомовній праці політик знову наголошував, що чехи і словаки - це «дві гілки тої самої нації», які «розмовляють тією ж мовою», «словацький діалект незначною мірою відрізняється від чеської мови» $[9$, с. 1$]$.

Схожу думку висловив і перший президент Чехословаччини Томаш Гарріг Масарик: «Чехи і словаки - один народ, що має спільну мову. [...] Між чехами і словаками не виникне питання мовних кордонів» [40, с. 13].

Згідно $з$ теорією чехословакізму, чехословацька мова має два різновиди: західна (чеська) та східна (словацька). У західній половині Чехословацької Республіки (на чеських територіях) побутує один варіант, а в східних (словацьких) регіонах - інший [3, с. 248]. Це було чітко передбачено § 4 Закону № 122 «Про мови» від 29 лютого 1920 року [4].

Постанова № 17/1926, ухвалена 4 лютого 1926 року (так звана «мовна постанова»), детально регулювала вживання мов. Цей документ кодифікував офіційну багатомовність Чехословацької Республіки [41, с. 37-46]. Цю багатомовність можемо спостерігати й на чехословацьких банкнотах.

Лицевий бік нової крони, що була запущена в обіг 1926 року, уже після ухвалення Конституції, Закону «Про мови» та «мовної» постанови, і надалі залишилася тільки одномовною (фото 5 та 7). Однак ця мова була вже не чеською - а згідно 3 правовими документами (Конституцією, Законом «Про мови» та «мовною» постановою), що втілювали ідеологію чехословакізму - де-юре була чехословацькою (хоча насправді де-факто залишалася тією ж чеською). 


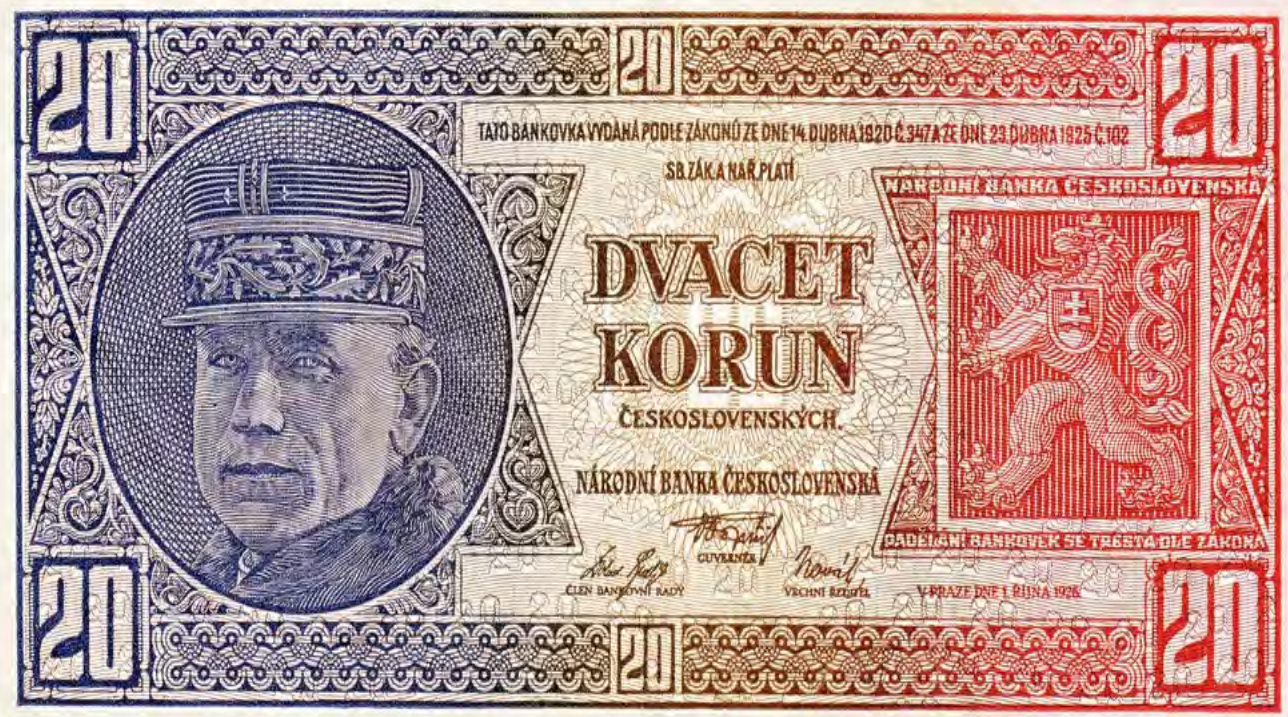

Використання мов на паперових грошах регулювалося абзацом (1) статті 13 «мовної» постанови від 1926 року. У документі, зокрема, ішлося: «Металеві та паперові гроші, а також марки про сплату державного мита видаються державною мовою». Однак абзацом (2) передбачалося, що «номінал паперових грошей на зворотному боці, у разі потреби, може вказуватися мовами національних меншин Чехословацької Республіки» [41, с. 52].

Тому на зворотному боці банкнот, поряд з державною мовою, номінал грошової одиниці вказувався українською / руською, німецькою й угорською мовами; натомість текст польською мовою, який був на грошах попередніх років випуску, тут зник (фото 6 та 8).

Куди ж поділася польська мова, напис якою ще був на кронах першого випуску? Вона зникла звідти через політичні причини.

Фото 6

Зворотний бік банкноти номіналом 20 крон, на якій текст «чехословацькою», українською, німецькою та угорською мовами; польської мови вже немає на банкноті

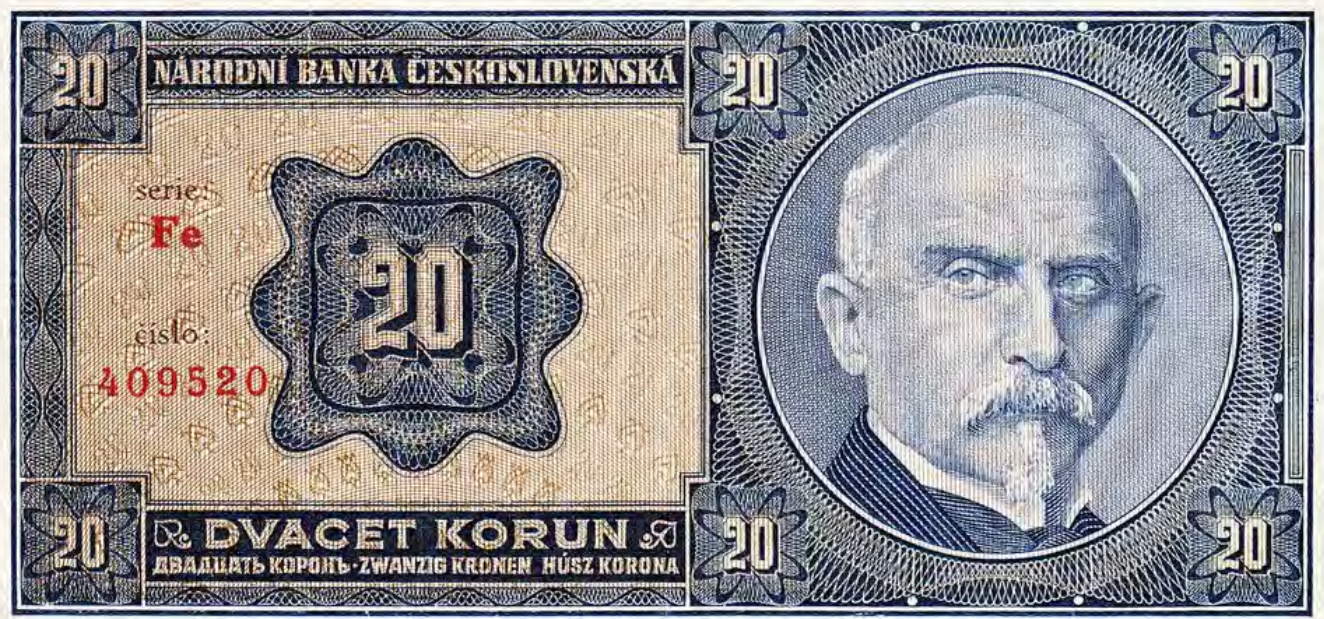


У 1919 році між Чехословаччиною та Польщею розгорівся територіальний конфлікт. Обидві сторони, тобто нова чехословацька держава й Польща, яка нещодавно повернула собі незалежність, заявили про свої претензії на містечко Цешин (німецькою Teschen, чеською Český Těšin, польською Cieszyn) та його околиці, що були раніше територією АвстроУгорщини. Територіальну суперечку між Чехословаччиною та Польщею зрештою вдалося залагодити укладеною 28 липня 1920 року міжнародною угодою, що передбачала поділ територій, зокрема й самого міста, між двома державами [62, с. 178]. Тож під час випуску нових банкнот 1926 року Чехословацька Республіка вже не вважала за потрібне подавати на нових кронах текст і польською мовою, адже політична мотивація такого кроку зникла. Прага вже не прагнула показати себе з позитивного боку перед польською нацменшиною. I це попри те, що з 1921 по 1931 рік ця меншина збільшилася на кілька тисяч осіб: з 75,8 тис. аж до 81,7 тис. (див. у таблиці № 1).

Фото 7

Лицевий бік банкноти 1926 року першої Чехословацької Республіки номіналом 50 крон, виконана «чехословацькою» мовою (польської мови вже немас)

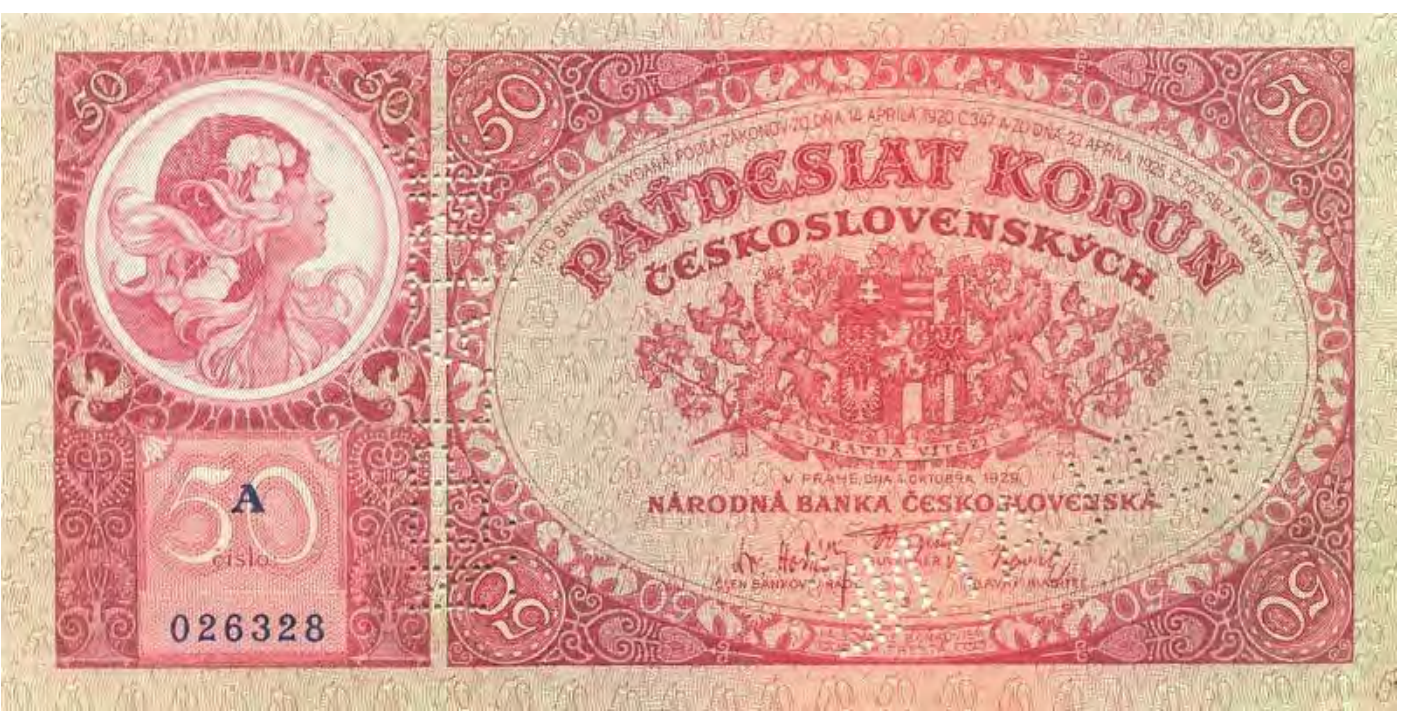

Фото 8

Зворотний бік банкноти номіналом 50 крон, на якій текст «чехословацькою», українською, німецькою та угорською мовами

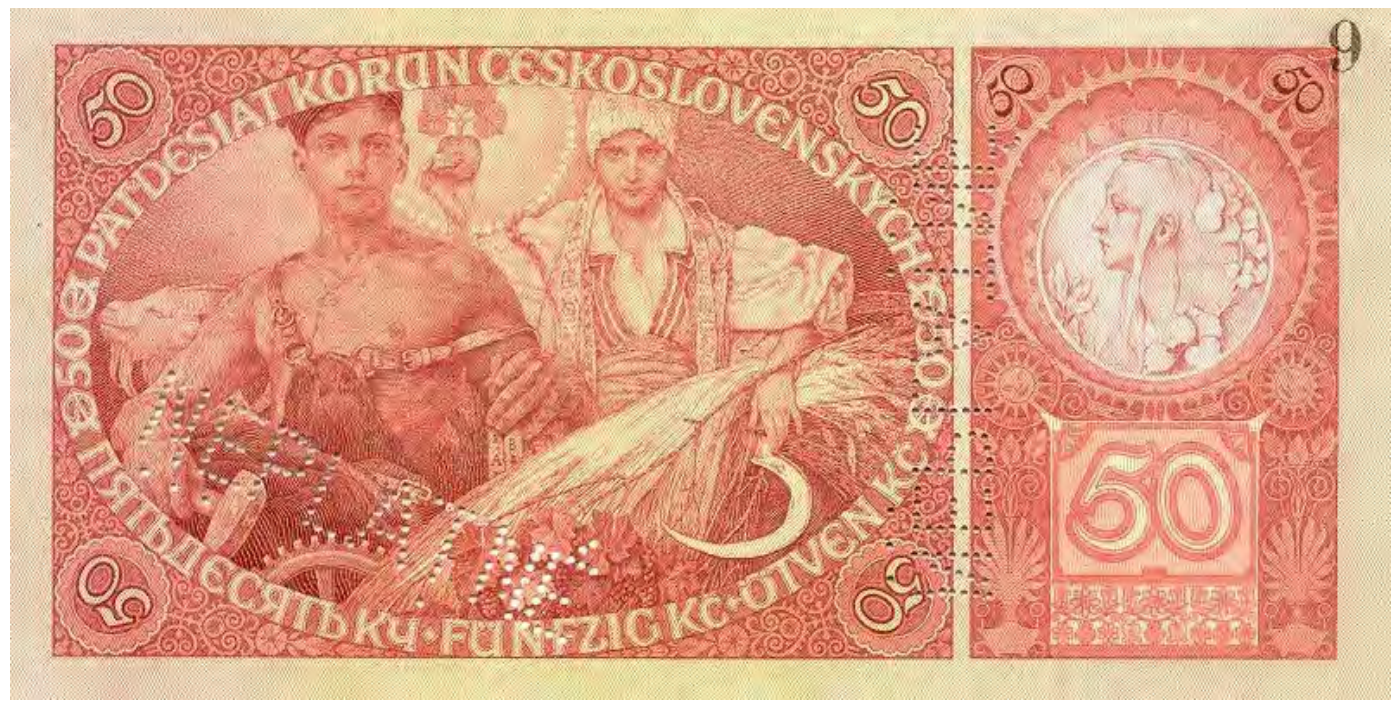


Аніко Берегсасі, Вільмоши Газдаг, Степан Черничко. Мовна політика і мовний ландшафт: Польська мова на банкнотах чехословацької республіки 1919-1938 рр.

\section{Ієрархічні відносини мовних ідеологій та мов.}

Нерідко квалітативний аналіз дає нам більше інформації про мовну політику та мовні ідеології окремих держав, ніж квантитативний. Як ми вже відзначали в першій частині нашого дослідження, завдяки квалітативному аналізу ми спробуємо розкрити, як через мовний ландшафт транслюються символічні змісти та мовні ідеології.

Елементи мовного ландшафту можна трактувати як символи [10, с. 8; 65], що характеризують «стан і владний статус» мов меншин [27, с. 32]. Написи мовами, що мають домінантний або особливий статус, переважно розташовують зверху, зліва або по центру, а написи так званими підпорядкованими мовами - здебільшого внизу, справа або на краю таблиць, купюр тощо [51, с. 120]. Отже, короткі тексти на банкнотах передають важливе послання про те, як бачить центральна влада становище мов у країні стосовно одна одної [28, с. 513]. Якщо зосередитися не тільки на змісті тексту, а й на розташуванні написів різними мовами, можна спостерегти, якими з погляду влади $є$ ієрархічні відносини між мовами, що використовуються на території держави.

М. Себба називає 4 підходи, на основі яких можна визначити, чи символізують написи на грошах мовну рівноправність. Якщо всі підходи на банкнотах реалізовані, то це, на думку науковця, свідчить про підтримку державою ідеї мовної рівноправності.

Ці підходи такі [52, с. 109]:

1. Дзеркальне розташування мов: на банкнотах мови розташовані як дзеркальне відображення. Як ми бачимо на чехословацьких банкнотах, це не є характерно.

2. Однаковий шрифт букв: написи всіма мовами виконані в одному розмірі. На всіх грошових одиницях Чехословаччини в досліджуваному періоді напис офіційною (державною) мовою країни значно більший за інші.

3. Ідентичність змісту та кількості тексту: заради рівноправності всіма мовами нанесено ту саму кількість та зміст тексту. На всіх аналізованих банкнотах мовами меншин указується тільки номінал. До того ж це найменш важливий текст на банкнотах, оскільки номінал ми переважно визначаємо за добре видними й виділеними цифрами.

4. Зміна порядку $i$ / або позиції: якще держава має кілька офіиійних мов, їх рівноправність можна засвідчити так, щуо на одному бочі банкнот зліва або зверху розташований напис однією мовою, а на зворотному - іншою. М. Себба в цьому контексті наводить приклад канадського долара: на 5-доларовій банкноті номінал вказано спочатку французькою, а потім англійською, а назва національного банку - навпаки; на 10-доларовій купюрі все це розташовано у зворотній послідовності [52, с. 110-111]. На всіх аналізованих нами банкнотах Чехословацької Республіки офіційна мова держави має пріоритетне розташування. Характерно й те, що на лицевому боці банкнот є напис тільки державною мовою, а мови меншин використані лише на зворотному.

Отже, із перерахованих М. Себбою підходів, на банкнотах Чехословацької Республіки не використовується жодний. Тож загальна картина свідчить, що держава, використовуючи багатомовність на своїх банкнотах, показує, як домінує офіційна мова 3-поміж інших, які використовуються в країні. Мови меншин на грошах з'являються тільки символічно, що не дивно, якщо взяти до уваги, що «появу мов меншин у мовному ландшафті переважно використовують як алібі» [39, с. 7]. Наявність мов меншин, зокрема, на банкнотах, може призвести до того, що більшість вважає мовну політику на користь мови меншини достатньою. Проте, сам факт існування мови меншини в мовному ландшафті, зокрема й на паперових грошових одиницях, сам по собі не обов'язково сприяє більшій повазі до мов меншин або більш широкого просування їх через такі заходи, як збільшення присутності цих мов у системі освіти чи їх використання органами державної влади [25, с. 486]. Уживання мов меншин у такий спосіб у публічному просторі сприяє візуальному посиленню мовної нерівноправності.

Наявність мов меншин на банкнотах вказує й на ієрархію серед цих мов. Ми бачимо, що хоча євреї становили $1,4 \%$ населення Чехословаччини, мова ідиш не зображена на паперових грошах держави. Символічне й те, що польська мова, як мова національної 
меншини, спочатку з'явилася на банкнотах, але пізніше зникла зі зворотного боку купюр. У цьому відображається зміна ставлення державної влади до польської меншини та мови.

Висновки та перспективи подальших досліджень. У дослідженні простежено, якими мовами були написи на грошових одиницях, котрі перебували в обігу на території Чехословацької Республіки в період між першою та другою світовими війнами. 3'ясувалося, що мешканці країни розраховувалися грошима, де були написи різними мовами: хоча лицевий бік грошових одиниць був одномовним, інший - багатомовним.

Мовний ландшафт може функціонувати як механізм, який нав'язує деякі мови домінантними, а інші - не-домінантними за допомогою мовної політики [25, с. 490-491]. Так, Чехословацької Республіка, що використовувала багатомовні гроші, прагнула, щоб національна мова державотворчої нації була на банкноті в панівній позиції. Це частково сигналізувалося тим, що лицевий бік банкноти був одномовним. Крім цього, напис мовою 3 домінантним становищем на зворотному боці був більшого розміру, розміщений в центрі або зверху, а написи іншими мовами - меншого розміру і / або не по центру. Недомінантними мовами напис був менш важливого змісту (зазначався лише номінал).

Якщо банкноти трактувати як елемент мовного ландшафту, відображення державної мовної політики, засоби символічної мовної політики, то можна стверджувати, що перша Чехословацька Республіка між двома світовими війнами намагалася показати себе як толерантну до національностей, багатомовну державу. Щоправда на країну можемо поширювати твердження, яке Л. Гренобль ужив стосовно мовної політики СРСР: існувала різниця між публічно декларованою мовною політикою та реальною практикою [26, с. 7].

Політичні зміни часто призводять до так званої «linguistic erasure» [30], тобто до зникнення певних мов 3 публічного простору, у нашому випадку - 3 банкнот. Це мало не тільки практичні наслідки, але й символічні: адже невикористання певної мови символізувало пониження іï статусу $[11$, с. 16]. Поява й зникнення польської мови 3 банкнотів Чехословацької Республіки є прикладом цього. Польська мова була відображена на чехословацьких банкнотах, що були в обігу між 1919-1925 pр., але Прага зняла польську мову з паперових грошей після 1926 року, коли змінилася політична мета держави.

\section{Список використаних джерел та літератури}

1. Берегсасі А., Черничко С. Гроші та (мовна) політика: візуальна конструкція мовної політики на банкнотах на території сучасного Закарпаття. Терекбалінт : Терміни, 2020. 120 с.

2. Черничко С., Фединець Ч. Наш місцевий Вавилон. Історія мовної політики на території Закарпаття у першій половині XX століття (до 1944 року). Ужгород : Поліграфцентр «Ліра», 2014. 58 с.

3. Шевельов Ю. Українська мова в першій половині двадцятого століття (1900-1941). Стан і статус. Київ : Сучасність, 1987. 295 с.

4. 122/1920 Sb. Zákon podle $\S 129$ ústavní listiny, jímž se stanoví zásady jazykového práva v republice Československé. URL : http://ftp.aspi.cz/opispdf/1920/026-1920.pdf (дата звернення 13.03.2020).

5. Backhaus P. Signs of multilingualism in Tokyo: A diachronic look at the linguistic landscape. International Journal of the Sociology of Language 175/176. 2005. P. 103-121.

6. Backhaus P. Multilingualism in Tokyo: A Look into the Linguistic Landscape. International Journal of Multilingualism 3(1). 2006. P. 52-66.

7. Backhaus P. Linguistic Landscapes: A Comparative Study of Urban Multilingualism in Tokyo. Clevedon : Multilingual Matters, 2007. 158 p.

8. Beneš E. Détruisez l'Autriche-Hongrie! La Martyre des Tchéco-Slovaques à travers l'Histoire. Paris : Librairie Delagrave, 1916. $82 \mathrm{p}$.

9. Beneš E. Bohemia's Case for Independence. London : Allen and Unwin, 1917. 154 p.

10. Ben-Rafael E., Shohamy E., Amara M. H., Trumper-Hecht N. Linguistic landscape as symbolic construction of the public space: The case of Israel. Linguistic landscape: A new approach to multilingualism / ed. D. Gorter. Clevedon : Multilingual Matters, 2006. P. 7-30.

11. Berezkina M. Language is a costly and complicating factor: a diachronic study of language policy in the virtual public sector. Language Policy 17. 2018. P. 55-75.

12. Blackwood R., Lanza E., Hirut W. eds. Negotiating and Contesting Identities in Linguistic Landscape. London : Bloomsbury Academic, 2016. 288 p. 
Аніко Берегсасі, Вільмош Газдаг, Степан Черничко. Мовна політика і мовний ландиафт: Польська мова на банкнотах чехословацької республіки 1919-1938 рр.

13. Blommaert J. Language Policy and National Identity. An Introduction to Language Policy: Theory and Method / ed. T. Ricento. Malden, MA : Blackwell Publishing Ltd., 2006. P. 238-254.

14. Blommaert J., Maly I. Ethnographic linguistic landscape analysis and social change: A case study. Tilburg Papers in Culture Studies, Paper 100. 2014. 28 p. URL: http://www.researchgate.net/publication/264992781_Ethnographic_Linguistic_Landscape_Analysis_and_ social_change_A_case_study (дата звернення 10.03.2020).

15. Bochmann K. A nyelvpolitika elmélete, módszerei és elemzése. Nyelv, hatalom, egyenlöség. Nyelvpolitikai írások / szerk G. Szépe, A. Derényi. Budapest : Corvina, 1999. P. 25-69.

16. Csernicskó I., Beregszászi A. Different states, same practices: visual construction of language policy on banknotes in the territory of present-day Transcarpathia. Language Policy 18(2). 2019. P. 269-293. URL : https://doi.org/10.1007/s10993-018-9485-3 (дата звернення 13.03.2020).

17. Dal Negro S. Local policy modeling the linguistic landscape. Linguistic landscape. Expanding the scenery / eds. E. Shohamy, D. Gorter. New York \& London : Routledge, 2009. P. 206-218.

18. Fairclough N. Critical discourse analysis: The critical study of Language. London : Longman, 1995. 265 p.

19. Fairclough N. Language and power ( $2^{\text {nd }}$ ed.). London: Longman, 2001. 226 p.

20. Gorter D. Further Possibilities for Linguistic Landscape Research. Linguistic Landscape: A New Approach to Multilingualism / ed. D. Gorter. Clevedon-Buffalo-Toronto : Multilingual Matters, 2006. P. 81-89.

21. Gorter D. Introduction: The Study of the Linguistic Landscape as a New Approach to Multilingualism. Linguistic Landscape: A New Approach to Multilingualism / ed. D. Gorter. Clevedon-Buffalo-Toronto : Multilingual Matters, 2006. P. 1-6.

22. Gorter D. Linguistic Landscapes in a Multilingual World. ARAL - Annual Review of Applied Linguistics 33. 2013. P. 190-212.

23. Gorter D. ed. Linguistic Landscape: A New Approach to Multilingualism. Clevedon-Buffalo-Toronto : Multilingual Matters, 2006. 89 p.

24. Gorter D., Marten H. F., Van Mensel L. eds. Minority Languages in the Linguistic Landscape. Basingstoke : Palgrave Macmillan, 2012. 335 p.

25. Gorter D., Marten H. F., Van Mensel, L. Linguistic Landscapes and Minority Languages. The Palgrave Handbook of Minority Languages and Communities / eds. G. Hogan-Brun, B. O’Rourke. London: Palgrave Macmillan, 2019. P. 481-506.

26. Grenoble L. A. Language Policy in the Soviet Union. New York-Boston-Dordrecht-London, Moscow : Kluwer Academic Publishers, 2003. 240 p.

27. Huebner T. Bangkok's linguistic landscapes. Environmental print, codemixing and language change. Linguistic landscape. A new approach to multilingualism / ed. D. Gorter. Clevedon: Multilingual Matters, 2006. P. 31-51.

28. Hult F. M. Drive-thru linguistic landscaping: Constructing a linguistically dominant place in a bilingual space. International Journal of Bilingualism 18(5). 2014. P. 507-523.

29. Hymans J. E. C. International Patterns in National Identity Content: The Case of Japanese Banknote Iconography. Journal of East Asian Studies 5. 2005. P. 315-346.

30. Irvine J. T., Gal S. Language ideology and linguistic differentiation. Regimes of language / ed. P. Kroskrity. Santa Fe : School of American Research Press, 2000. P. 35-83.

31. Jaworski A., Thurlow C. Introducing Semiotic Landscapes. Semiotic Landscapes: Language, Image, Space / eds A. Jaworski, C. Thurlow. London : Continuum, 2010. P. 1-40.

32. Jaworski A., Thurlow C. eds. Semiotic landscapes: Language, image, space. London : Continuum, 2010. $320 \mathrm{p}$.

33. Kamusella T. The Politics of Language and Nationalism in Modern Central Europe. Basingstoke : Palgrave Macmillan, 2009. $896 \mathrm{p}$.

34. Kroon S., Van der Aa J-L., Asfaha Y. M. English in Asmara as a Changing Reflection of Online Globalization. Language and Culture on the Margins: Global/Local Interactions / eds. S. Kroon, J. Swanenberg. New York-London : Routledge, 2019. P. 53-68.

35. Kroskrity P. V. Regimenting language. Regimes of Language: Ideologies, Polities and Identities / ed. P. V. Kroskrity. Santa Fe : School of American Research Advanced Seminar Series, 2000. P. 1-34.

36. Laihonen P. Linguistic landscapes of a minoritized regional majority: Language ideologies among Hungarians in South-West Slovakia. Dimensions of Sociolinguistic Landscapes in Europe Materials and Methodological Solutions / eds. M. Laitinen, A. Zabrodskaja. Peter Lang, Frankfurt am Main, Berlin, Bern, Bruxelles, New York, Oxford, Wien, 2015. P. 171-198.

37. Landry R., Bourhis R. Y. Linguistic landscape and ethnolinguistic vitality: An empirical study. Journal of Language and Social Psychology 16(1). 1997. P. 23-49. 
38. Mark D. M., Turk A. G., Burenhult N., Stea D. eds. Landscape in language: Transdisciplinary perspectives. Amsterdam : Philadelphia John Benjamins, 2011. 464 p.

39. Heiko F. M., Van Mensel L., Gorter D. Studying Minority Languages in the Linguistic Landscape. Minority Languages in the Linguistic Landscape / eds. D. Gorter, F. M. Heiko, L. Van Mensel. Basingstoke : Palgrave Macmillan, 2012. P. 1-15.

40. Masaryk T. G. Světová revoluce: Za války a ve válce, 1914-1918. Prague : Orbis, 1925. 650 p.

41. Orosz Ö. ed. A hely nevei, a nyelv helyei. A kisebbségi nyelvi jogok története Szlovákiában 1918-2012. Somorja : Fórum Kisebbségkutató Intézet. 2012. 176 p.

42. Pavlenko A. Language Conflict in Post-Soviet Linguistic Landscapes. Journal of Slavic Linguistics 17 (12). 2009. P. 247-274.

43. Pavlenko A. Linguistic Landscape of Kyiv, Ukraine: A Diachronic Study. Linguistic Landscape in the City / eds. E. Shohamy, E. Ben-Rafael, M. Barni. Bristol-Buffalo-Toronto : Multilingual Matters, 2010. P. 133-150.

44. Pavlenko A. Why diachronicity matters in the study of linguistic landscapes. Linguistic Landscape 1 (1/2). 2015. P. 114-132.

45. Pennycook A. Translanguaging and semiotic assemblages. International Journal of Multilingualism 14 (3). 2017. P. 269-282.

46. Pomichál R. Csehszlovákia és Magyarország viszonya az 1920-as években. Fórum Társadalomtudományi Szemle 2007/2. 2007. P. 63-85.

47. Puzey G. Two-Way Traffic: How Linguistic Landscapes Reflect and Influence the Politics of Language. Minority Languages in the Linguistic Landscape / eds. D. Gorter, H. F. Marten, L. Van Mensel. Basingstoke : Palgrave Macmillan, 2012. P. 127-147.

48. Raento P., Hämäläinen A., Ikonen H., Mikkonen N. Striking Stories. A Political Geography of Euro Coinage. Political Geography 23/8. 2004. P. 929-995.

49. Romsics I. Magyarország története a XX században. Budapest : Osiris, 2010. 688 p.

50. Rubdy R., Ben Said S. eds. Conflict, Exclusion and Dissent in the Linguistic Landscape. Basingstoke : Palgrave MacMillan, 2015. 306 p.

51. Scollon R., Scollon S. W. Discourses in place: Language in the material world. London, UK : Routledge, 2003. $242 \mathrm{p}$.

52. Sebba M. The visual construction of language hierarchy: The case of banknotes, coins and stamps. Journal of Language and Politics 12(1). 2013. P. 101-125.

53. Shohamy E. Language policy: Hidden agendas and new approaches. London : Routledge, 2006. 185 p.

54. Shohamy E. Linguistic Landscapes and Multilingualism. The Routledge Handbook of Multilingualism / eds. M. Martin-Jones, A. Blackledge, A. Creese. New York : Routledge, 2012. P. 538-551.

55. Shohamy E. LL research as expanding language and language policy. Linguistic Landscape 1(1/2). 2015. P. $152-171$.

56. Shohamy E., Ben-Rafael E. Introduction: linguistic landscape, a new journal. Linguistic Landscsape 1(1/2). 2015. P. 1-5.

57. Shohamy E., Gorter D. Introduction. Linguistic Landscape: Expanding the Scenery / eds. E. Shohamy, D. Gorter. New York : Routledge, 2009. P. 1-10.

58. Shohamy E., Gorter D. eds. Linguistic landscape: Expanding the scenery. New York : Routledge, 2009. $352 \mathrm{p}$.

59. Shohamy E., Waksman S. Linguistic landscape as an ecological arena: Modalities, meanings, negotiations, education. Linguistic landscape: Expanding the scenery / eds. E. Shohamy, D. Gorter. New York-London : Routledge, 2009. P. 313-331.

60. Spolsky B. Language Policy. Cambridge : Cambridge University Press, 2004. 250 p.

61. Szarka L. A multietnikus nemzetállam. Kísérletek, kudarcok és kompromisszumok Csehszlovákia nemzetiségi politikájában 1918-1992. Pozsony : Kalligram, 2016.376 p.

62. Tóth A., Novotný L., Stehlík M. Národnostní menšiny v Československu 1918-1938. Praha : Univerzita Kralova v Praze, Filozofická fakulta, 2012. $722 \mathrm{~s}$.

63. Tufi S., Blackwood R. Trademarks in the linguistic landscape: Methodological and theoretical challenges in qualifying brand names in the public space. International Journal of Multilingualism 7. 2010. P. 197210.

64. Veselkova M., Horvath J. National identity and money: Czech and Slovak Lands 1918-2008. Nationalities Papers 39(2). 2011. P. 237-255.

65. Vigers D. Signs of absence: language and memory in the linguistic landscape of Brittany. International Journal of the Sociology of Language 223. 2013. P. 171-187. 


\section{References (translated \& transliterated)}

1. Berehsasi, A., \& Chernychko, S. (2020). Hroshi ta (movna) polityka: vizualna konstruktsiia movnoi polityky na banknotakh na terytorii suchasnoho Zakarpattia [Money and (language) policy: visual construction of language policy on banknotes in the territory of modern Transcarpathia]. Terekbalint: Terminy [In Ukrainian].

2. Chernychko, S., \& Fedynets, C. (2014). Nash mistsevyi Vavylon. Istoriia movnoi polityky na terytorii Zakarpattia u pershii polovyni XX stolittia (do 1944 roku) [Our local Babylon. History of language policy in Transcarpathia in the first half of the twentieth century (until 1944)]. Uzhhorod: Polihraftsentr «Lira» [In Ukrainian].

3. Shevelov, Yu. (1987). Ukrainska mova v pershii polovyni dvadtsiatoho stolittia (1900-1941). Stan i status [Ukrainian language in the first half of the twentieth century (1900-1941). Situation and status]. Kyiv: Suchasnist [In Ukrainian].

4. 122/1920 Sb. Zákon podle $§ 129$ ústavní listiny, jímž se stanoví zásady jazykového práva v republice Československé [122/1920 Sb. Act pursuant to Section 129 of the Constitutional Charter, which lays down the principles of language law in the Czechoslovak Republic]. ftp.aspi.cz. Retrieved from http://ftp.aspi.cz/opispdf/1920/026-1920.pdf [In Czech].

5. Backhaus, P. (2005). Signs of multilingualism in Tokyo: A diachronic look at the linguistic landscape. International Journal of the Sociology of Language, 175/176, 103-121 [In English].

6. Backhaus, P. (2006). Multilingualism in Tokyo: A Look into the Linguistic Landscape. International Journal of Multilingualism, 3(1), 52-66 [In English].

7. Backhaus, P. (2007). Linguistic Landscapes: A Comparative Study of Urban Multilingualism in Tokyo. Clevedon: Multilingual Matters [In English].

8. Beneš, E. (1916). Détruisez l'Autriche-Hongrie! La Martyre des Tchéco-Slovaques à travers l'Histoire. Paris: Librairie Delagrave [In French].

9. Beneš, E. (1917). Bohemia's Case for Independence. London: Allen and Unwin [In English].

10. Ben-Rafael, E., Shohamy, E., Amara, M. H., \& Trumper-Hecht, N. (2006). Linguistic landscape as symbolic construction of the public space: The case of Israel. Linguistic landscape: A new approach to multilingualism. D. Gorter (Ed.). Clevedon: Multilingual Matters [In English].

11. Berezkina, M. (2018). Language is a costly and complicating factor: a diachronic study of language policy in the virtual public sector. Language Policy, 17, 55-75 [In English].

12. Blackwood, R., Lanza, E., \& Woldemariam, H. (Eds.) (2016). Negotiating and Contesting Identities in Linguistic Landscape. London: Bloomsbury Academic [In English].

13. Blommaert, J. (2006). Language Policy and National Identity. T. Ricento (Ed.), An Introduction to Language Policy: Theory and Method (pp. 238-254). Malden, MA: Blackwell Publishing Ltd. [In English].

14. Blommaert, J., \& Maly, I. (2014). Ethnographic linguistic landscape analysis and social change: A case study. Tilburg Papers in Culture Studies, paper 100. Retrieved from http://www.researchgate.net/publication/264992781_Ethnographic_Linguistic_Landscape_Analysis_and_ social_change_A_case_study [In English].

15. Bochmann, K. (1999). A nyelvpolitika elmélete, módszerei és elemzése [Theory, methods and analysis of language policy]. G. Szépe, \& A. Derényi (Eds.), Nyelv, hatalom, egyenlöség. Nyelvpolitikai írások Language, power, equality. Language policy writings (pp. 25-69). Budapest: Corvina [In Hungarian].

16. Csernicskó, I., \& Beregszászi, A. (2019). Different states, same practices: visual construction of language policy on banknotes in the territory of present-day Transcarpathia. Language Policy, 18(2), 269-293. Retrieved from https://doi.org/10.1007/s10993-018-9485-3 [In English].

17. Dal Negro, S. (2009). Local policy modeling the linguistic landscape. E. Shohamy, \& D. Gorter (Eds.), Linguistic landscape. Expanding the scenery (pp. 206-218). New York \& London: Routledge [In English].

18. Fairclough, N. (1995). Critical discourse analysis: The critical study of Language. London: Longman [In English].

19. Fairclough, N. (2001). Language and power ( ${ }^{\text {nd }}$ ed.). London: Longman [In English].

20. Gorter, D. (2006a). Further Possibilities for Linguistic Landscape Research. D. Gorter (Ed.), Linguistic Landscape: A New Approach to Multilingualism (pp. 81-89). Clevedon-Buffalo-Toronto: Multilingual Matters [In English].

21. Gorter, D. (2006b). Introduction: The Study of the Linguistic Landscape as a New Approach to Multilingualism. D. Gorter (Ed.), Linguistic Landscape: A New Approach to Multilingualism (pp. 1-6). Clevedon-Buffalo-Toronto: Multilingual Matters [In English]. 
22. Gorter, D. (2013). Linguistic Landscapes in a Multilingual World. ARAL - Annual Review of Applied Linguistics, 33, 190-212 [In English].

23. Gorter, D. (Ed.) (2006). Linguistic Landscape: A New Approach to Multilingualism. Clevedon-BuffaloToronto: Multilingual Matters [In English].

24. Gorter, D., Marten, H. F., \& Van Mensel, L. (Eds.) (2012). Minority Languages in the Linguistic Landscape. Basingstoke: Palgrave Macmillan [In English].

25. Gorter, D., Marten, H. F., \& Van Mensel, L. (2019). Linguistic Landscapes and Minority Languages. G. Hogan-Brun, \& B. O'Rourke (Eds.), The Palgrave Handbook of Minority Languages and Communities (pp. 481-506). London: Palgrave Macmillan [In English].

26. Grenoble, L. A. (2003). Language Policy in the Soviet Union. New York-Boston-Dordrecht-London, Moscow: Kluwer Academic Publishers [In English].

27. Huebner, T. (2006). Bangkok's linguistic landscapes. Environmental print, codemixing and language change. D. Gorter (Ed.), Linguistic landscape. A new approach to multilingualism (pp. 31-51). Clevedon: Multilingual Matters [In English].

28. Hult, F. M. (2014). Drive-thru linguistic landscaping: Constructing a linguistically dominant place in a bilingual space. International Journal of Bilingualism, 18(5), 507-523 [In English].

29. Hymans, J. E. C. (2005). International Patterns in National Identity Content: The Case of Japanese Banknote Iconography. Journal of East Asian Studies, 5, 315-346 [In English].

30. Irvine, J. T., \& Gal, S. (2000). Language ideology and linguistic differentiation. P. Kroskrity (Ed.), Regimes of language (pp. 35-83). Santa Fe: School of American Research Press [In English].

31. Jaworski, A., \& Thurlow, C. (2010). Introducing Semiotic Landscapes. A. Jaworski, \& C. Thurlow (Eds.), Semiotic Landscapes: Language, Image, Space (pp. 1-40). London: Continuum [In English].

32. Jaworski, A., \& Thurlow, C. (Eds.). (2010). Semiotic landscapes: Language, image, space. London: Continuum [In English].

33. Kamusella, T. (2009). The Politics of Language and Nationalism in Modern Central Europe. Basingstoke: Palgrave Macmillan [In English].

34. Kroon, S., Van der Aa, J-L., \& Asfaha, Y. M. (2019). English in Asmara as a Changing Reflection of Online Globalization. S. Kroon, \& J. Swanenberg (Eds.), Language and Culture on the Margins: Global/Local Interactions (pp. 53-68). New York-London: Routledge [In English].

35. Kroskrity, P. V. (2000). Regimenting language. P. V. Kroskrity (Ed.), Regimes of Language: Ideologies, Polities and Identities (pp. 1-34). Santa Fe: School of American Research Advanced Seminar Series [In English].

36. Laihonen, P. (2015). Linguistic landscapes of a minoritized regional majority: Language ideologies among Hungarians in South-West Slovakia. M. Laitinen, \& A. Zabrodskaja (Eds.), Dimensions of Sociolinguistic Landscapes in Europe Materials and Methodological Solutions (pp. 171-198). Peter Lang, Frankfurt am Main, Berlin, Bern, Bruxelles, New York, Oxford, Wien [In English].

37. Landry, R., \& Bourhis, R. Y. (1997). Linguistic landscape and ethnolinguistic vitality: An empirical study. Journal of Language and Social Psychology, 16(1), 23-49 [In English].

38. Mark, D. M., Turk, A. G., Burenhult, N., \& Stea, D. (Eds.). (2011). Landscape in language: Transdisciplinary perspectives. Amsterdam: Philadelphia John Benjamins [In English].

39. Marten, F. H., Van Mensel, L., \& Gorter, D. (2012). Studying Minority Languages in the Linguistic Landscape. D. Gorter, H. F. Marten, \& L. Van Mensel (Eds.), Minority Languages in the Linguistic Landscape (pp. 1-15). Basingstoke: Palgrave Macmillan [In English].

40. Masaryk, T. G. (1925). Světová revoluce: Za války a ve válce, 1914-1918 [World Revolution: During War and War, 1914-1918]. Prague: Orbis [In Czech].

41. Orosz, Ö. (Ed.) (2012). A hely nevei, a nyelv helyei. A kisebbségi nyelvi jogok története Szlovákiában 1918-2012 [Place names, places of language. History of minority language rights in Slovakia 19182012]. Somorja: Fórum Kisebbségkutató Intézet [In Hungarian].

42. Pavlenko, A. (2009). Language Conflict in Post-Soviet Linguistic Landscapes. Journal of Slavic Linguistics, 17(1-2), 247-274 [In English].

43. Pavlenko, A. (2010). Linguistic Landscape of Kyiv, Ukraine: A Diachronic Study. E. Shohamy, E. BenRafael, \& M. Barni (Eds.), Linguistic Landscape in the City (pp. 133-150). Bristol-Buffalo-Toronto: Multilingual Matters [In English].

44. Pavlenko, A. (2015). Why diachronicity matters in the study of linguistic landscapes. Linguistic Landscape, 1(1/2), 114-132 [In English].

45. Pennycook, A. (2017). Translanguaging and semiotic assemblages. International Journal of Multilingualism, 14(3), 269-282 [In English]. 
Аніко Берегсасі, Вільмоши Газдаг, Степан Черничко. Мовна політика і мовний ландшафт:

Польська мова на банкнотах чехословацької республіки 1919-1938 рр.

46. Pomichál, R. (2007). Csehszlovákia és Magyarország viszonya az 1920-as években [Relationship between Czechoslovakia and Hungary in the 1920s]. Fórum Társadalomtudományi Szemle - Forum Social Science Review, 2007/2, 63-85 [In Hungarian].

47. Puzey, G. (2012). Two-Way Traffic: How Linguistic Landscapes Reflect and Influence the Politics of Language. D. Gorter, H. F. Marten, \& L. Van Mensel (Eds.), Minority Languages in the Linguistic Landscape (pp. 127-147). Basingstoke: Palgrave Macmillan [In English].

48. Raento, P., Hämäläinen, A., Ikonen, H., \& Mikkonen, N. (2004). Striking Stories. A Political Geography of Euro Coinage. Political Geography 23/8, 929-995 [In English].

49. Romsics, I. (2010). Magyarország története a XX században [History of Hungary in the 20th century]. Budapest: Osiris [In Hungarian].

50. Rubdy, R., \& Ben Said, S. (Eds.) (2015). Conflict, Exclusion and Dissent in the Linguistic Landscape. Basingstoke: Palgrave MacMillan [In English].

51. Scollon, R., \& Scollon, S. W. (2003). Discourses in place: Language in the material world. London, UK: Routledge [In English].

52. Sebba, M. (2013). The visual construction of language hierarchy: The case of banknotes, coins and stamps. Journal of Language and Politics, 12(1), 101-125 [In English].

53. Shohamy, E. (2006). Language policy: Hidden agendas and new approaches. London: Routledge [In English].

54. Shohamy, E. (2012). Linguistic Landscapes and Multilingualism. M. Martin-Jones, A. Blackledge, \& A. Creese (Eds.), The Routledge Handbook of Multilingualism (pp. 538-551). New York: Routledge [In English].

55. Shohamy, E. (2015). LL research as expanding language and language policy. Linguistic Landscape, 1(1/2), 152-171 [In English].

56. Shohamy, E., \& Ben-Rafael, E. (2015). Introduction: linguistic landscape, a new journal. Linguistic Landscsape, 1(1/2), 1-5 [In English].

57. Shohamy, E., \& Gorter, D. (2009). Introduction. E. Shohamy, \& D. Gorter (Eds.), Linguistic Landscape: Expanding the Scenery (pp. 1-10). New York: Routledge [In English].

58. Shohamy, E., \& Gorter, D. (Eds.) (2009). Linguistic landscape: Expanding the scenery. New York: Routledge [In English].

59. Shohamy, E., \& Waksman, S. (2009). Linguistic landscape as an ecological arena: Modalities, meanings, negotiations, education. E. Shohamy, \& D. Gorter (Eds.), Linguistic landscape: Expanding the scenery (pp. 313-331). New York-London: Routledge [In English].

60. Spolsky, B. (2004). Language Policy. Cambridge: Cambridge University Press [In English].

61. Szarka, L. (2016). A multietnikus nemzetállam. Kisérletek, kudarcok és kompromisszumok Csehszlovákia nemzetiségi politikájában 1918-1992 [The multi-ethnic nation-state. Attempts, Failures and Compromises in Czechoslovakia's Nationality Policy 1918-1992]. Pozsony: Kalligram [In Hungarian].

62. Tóth, A., Novotný, L., \& Stehlík, M. (2012). Národnostní menšiny v Československu 1918-1938 [National minorities in Czechoslovakia 1918-1938]. Praha: Univerzita Kralova v Praze, Filozofická fakulta [In Czech].

63. Tufi, S., \& Blackwood, R. (2010). Trademarks in the linguistic landscape: Methodological and theoretical challenges in qualifying brand names in the public space. International Journal of Multilingualism, 7 , 197-210 [In English].

64. Veselkova, M., \& Horvath, J. (2011). National identity and money: Czech and Slovak Lands 1918-2008. Nationalities Papers, 39(2), 237-255 [In English].

65. Vigers, D. (2013). Signs of absence: language and memory in the linguistic landscape of Brittany. International Journal of the Sociology of Language, 223, 171-187 [In English].

Статтю отримано 16.04.2020 p.

Прийнято до друку 18.05.2020 р. 